\title{
The Relationship of Resilience and Emotional Regulation with Life Expectancy among Soldiers
}

\author{
${ }^{*}$ Mohamadzade. $\mathrm{M}^{1}$ \\ Jahandari. $\mathrm{P}^{2}$ \\ 1- ( ${ }^{*}$ Corresponding Author) \\ MSc in General Psychology, \\ Faculty of Para Medicine, Aja \\ University of Medical Sciences, \\ Tehran, Iran \\ Email: mohsen.zade93@gmail.com \\ 2- MSc in Psychology \\ Consultation, Research \\ Institute for Military Medicine, \\ Aja University of Medical \\ Sciences, Tehran, Iran
}

\begin{abstract}
Introduction: Entry into the military service affects the mental health of individuals and one of the effective factors in mental health, especially in the current world, is the hope for a healthy life. The most important effect of hope is the improvement of motivation and activation. Hope is one of the variables that influence the happiness of people in society, especially the younger generation.
\end{abstract}

Objectives: The present study aimed at investigating the relationship of resilience and emotional regulation with life expectancy in soldiers.

Materials and Methods: The present descriptive-correlational study was conducted in 2017 on 300 soldiers selected by convenience sampling method. The data collection instruments were the Conner and Davidson resiliency, the Gross and John emotional regulation, and the Miller life expectancy questionnaires. The reliability and validity of the questionnaires were confirmed in previous studies. In the current study, the reliability and validity of the instruments were determined using the Cronbach alpha coefficient, which were $0.89,0.70$, and 0.91 , respectively. The collected data were analyzed using SPSS software version 20.

Results: The Pearson correlation coefficient showed the correlation of resilience and emotional regulation with soldiers' life expectancy $(\mathrm{P}<0.001)$. Resilience and emotional regulation had the potential for life expectancy in soldiers $(\mathrm{P}<0.05)$.

Discussion and Conclusion: The current study findings indicated a significant correlation of resilience and emotional regulation with life expectancy among soldiers. To increase the life expectancy in soldiers, the focused resilience training that increases the individual's resistance to stress and emotion regulation that influences the individuals' responses to different situations of life, especially in critical conditions, are essential.

Keywords: Emotional Regulation, Life Expectancy, Resilience, Soldiers. 


\section{بررسى رابطه بين تاب آورى و تنظيم هيجانى با اميد به زندكى در بين سربازان}

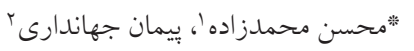

جكيده

مقدمه: ورود به سربازى سلامت روانى افراد را تحت تأثير قرار مىدهد و يكى از عواملى مؤثر در سلامت روان مخصوصاً

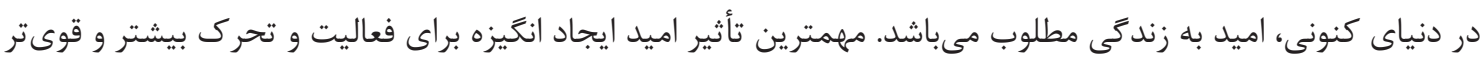

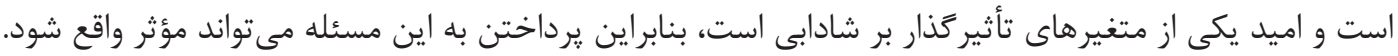

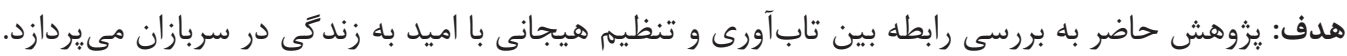

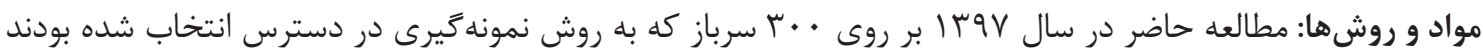

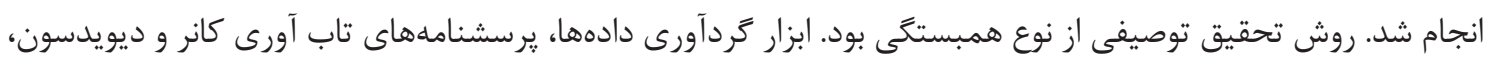

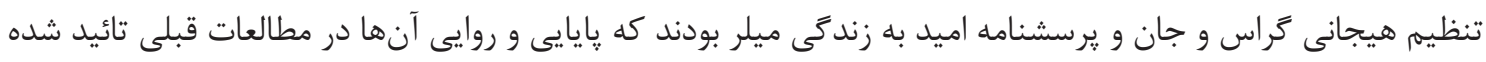

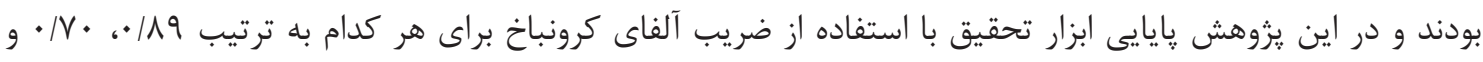

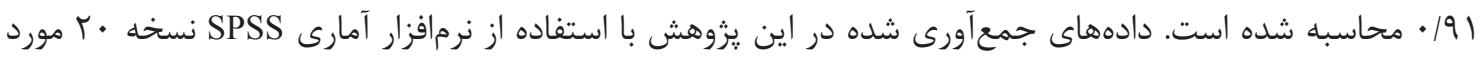
تجزيه و تحليل قرار كرفت. يافتها: نتايج آزمون ضريب همبستخى يقيرسون نشان داد كه بين تابآورى و تنظيم هيجانى با اميد به زندكى سربازان

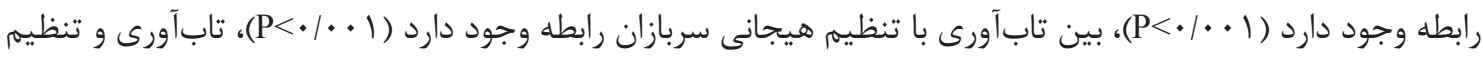

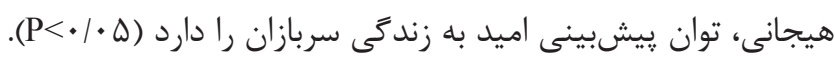

بحث و نتيجهَيرى: يافتهها بيانكَر آن است كه بين تابآورى و تنظيم هيجانى با اميد به زندكى در بين سربازان رابطه

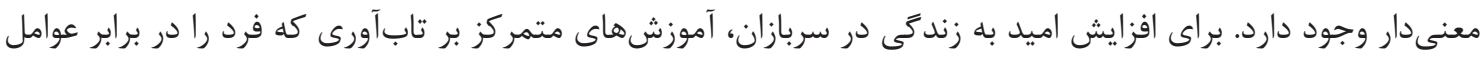

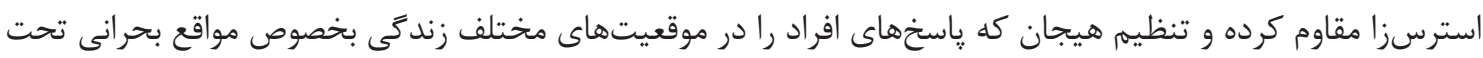

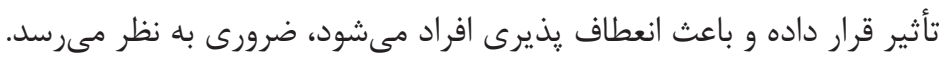
كلمات كليدى: اميد به زندگى، تاب آورى، تنظيم هيجانى، سرباز وران.

\begin{tabular}{|c|c|c|}
\hline 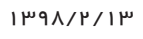 & تاريخ دريافت: ت & 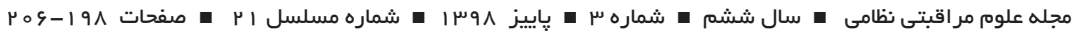 \\
\hline $\mid \mu q \wedge / \kappa / \mu r$ & تاريخ يذيرش: ت & \\
\hline १^/१/щ。 & 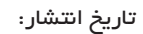 & \\
\hline
\end{tabular}

خود اطمينان و اعتماد دارند. مهارتهاى كفتتكو، جرأتمندى، مقلمهـ آمادَى براى گَوش دادن به ديكران و احترام كذاشتن به احساسات زندگى در جهان امروز ير از استرس و جالشهايى است كه افراد

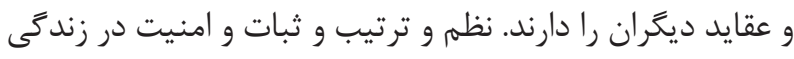
فردى را نيز دارند. احساس توانمندى در رويارويى با مشكلات

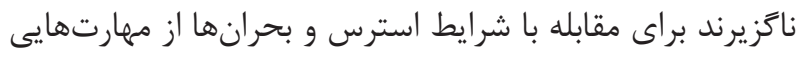

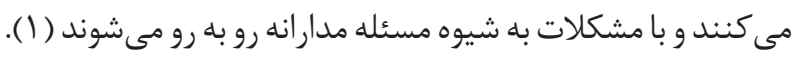
استفاده كنند. يكى از اين مهارتها تابآورى (Resilience)

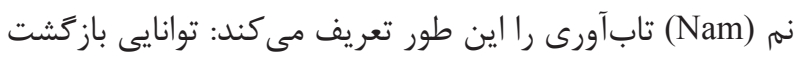

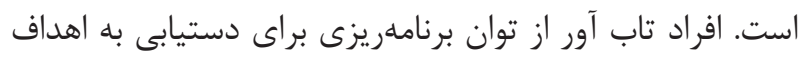

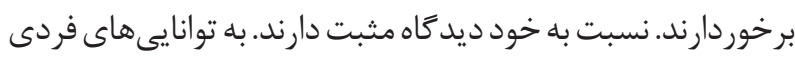


بيان كنند، جه راهكارهايى را در ياسخ به هيجانها به كار برند و

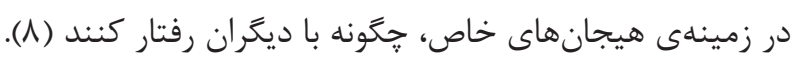

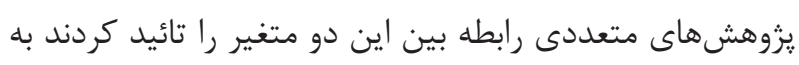

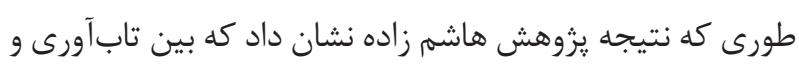

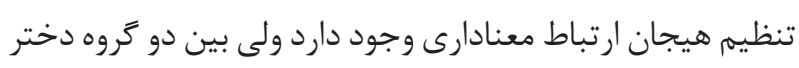

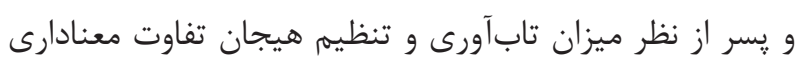

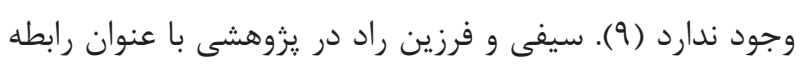
تنظيم هيجان، اضطراب و افسردىى با تابآورى در دانشجويان

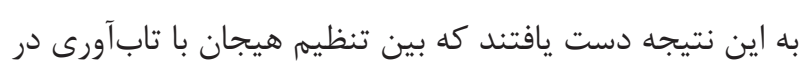

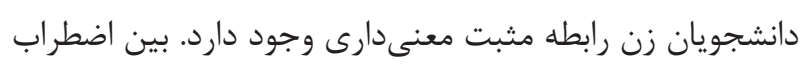

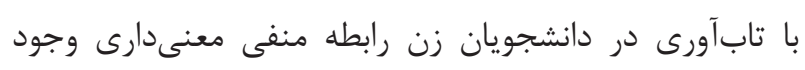

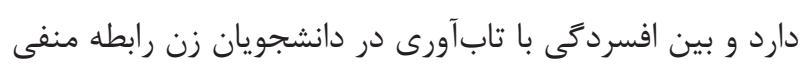

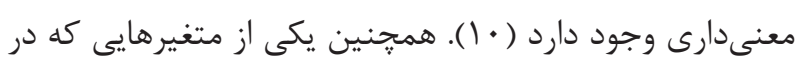

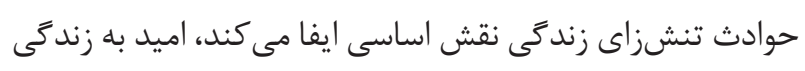

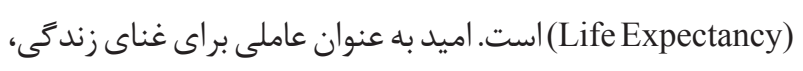

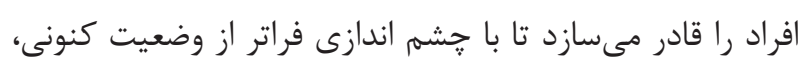

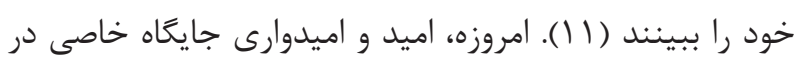
سلامتى روانى، جسمانى و به تبع آن، يِيشرفت فرد و جامعه دارد

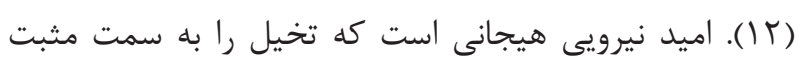

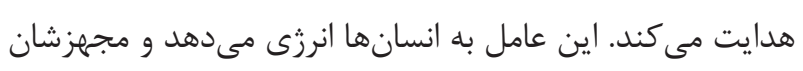
مى كند و مانند كاتاليزورى براى كار و فعاليت عمل مىنمايد (باين (1).

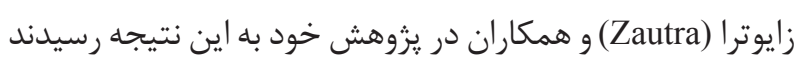

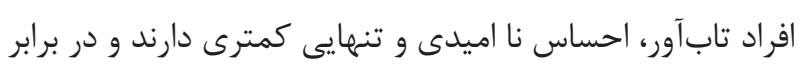

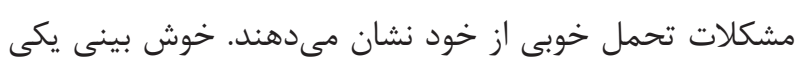

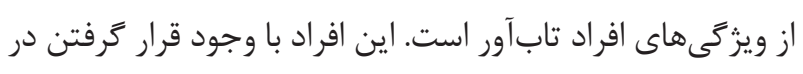

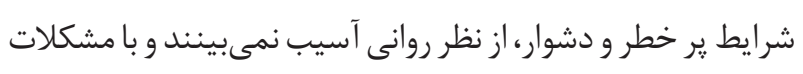

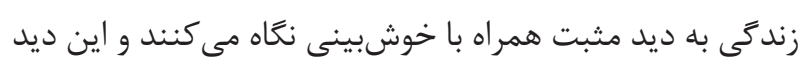

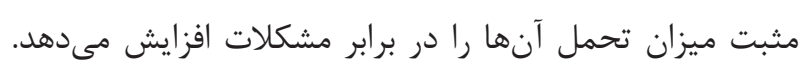

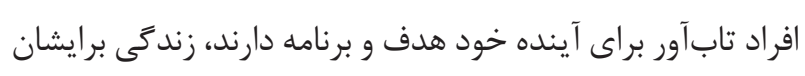

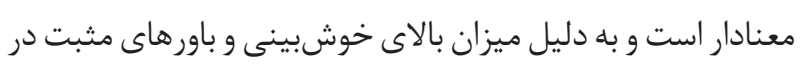

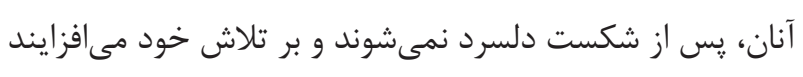

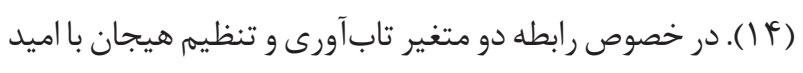
به زندكى يزوهشهاى متعدد صورت گرفته به طورى كه ناعمى

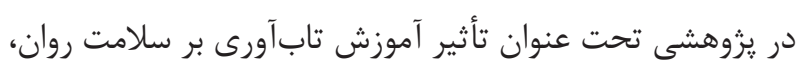

به حالت اول، تحمل كردن شوكها، استقامت كردن، حفظ

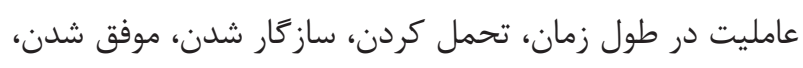

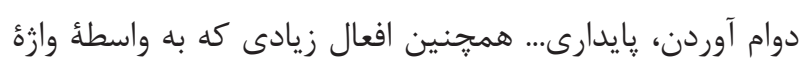

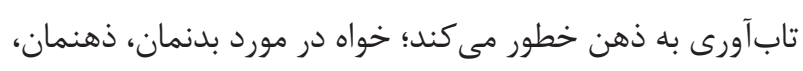
جامعلمان، نهادهايمان يا محيط طبيعىمان صحبت كنيم (Y) (Y).

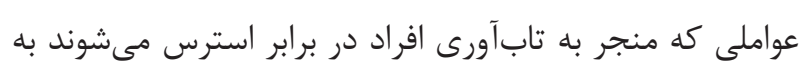

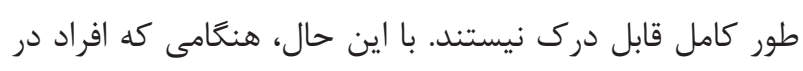

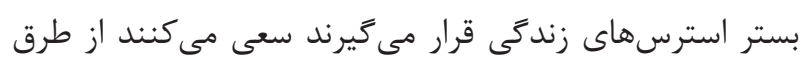

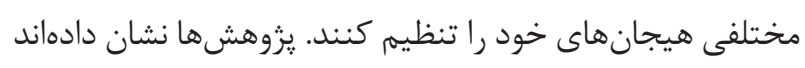

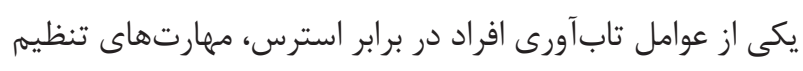
هيجان است (ب). متغير استراترىهاى تنظيم شناخت هيجان

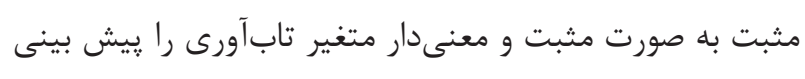

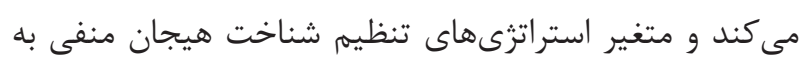

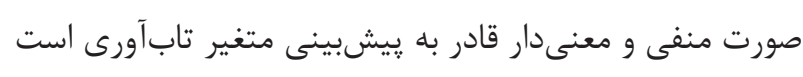
و بين تنظيم شناختى هيجان با تابآورى رابطه وجود دارد (1).

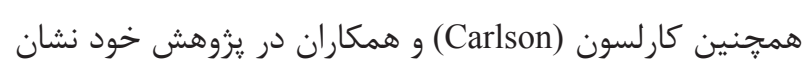

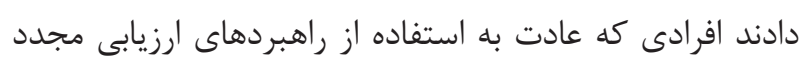

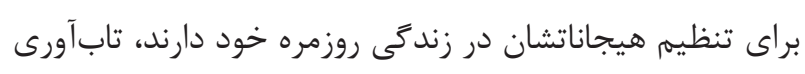
بيشترى در برابر استرس از خود نشان مى دئند

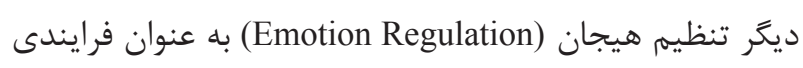
قلمداد مىشود كه از طريق آن افراد به اين آكاهى دست مى يابند

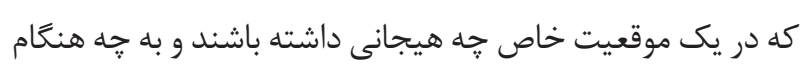
و به جه شكل آن را ابراز نمايند (ه).

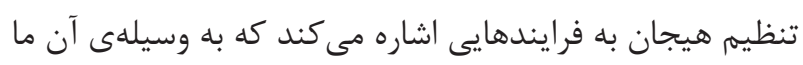

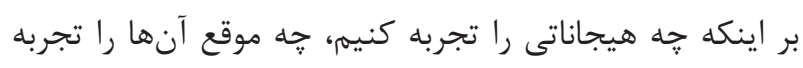

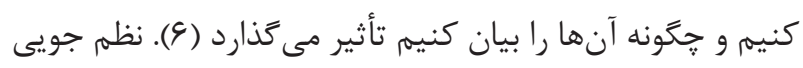
هيجانها مربوط به طيف وسيعى از حوزههاى عملكرد، از جمله:

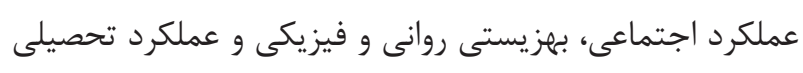

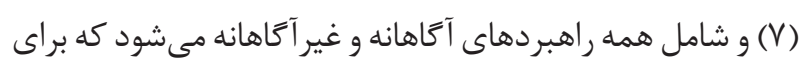
افزايش، حفظ و كاهش مؤلفههاى هيجانى، رفتارى و شناختى يك رهي

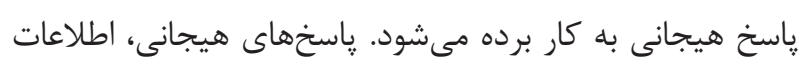

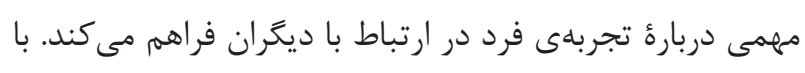

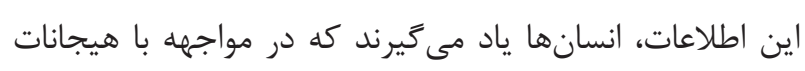

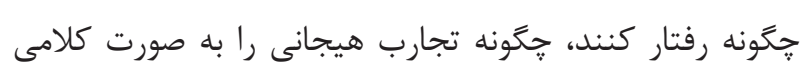


دسترس نايذير بيابند، دست از تلاش مى كشند و در نهايت تسليم

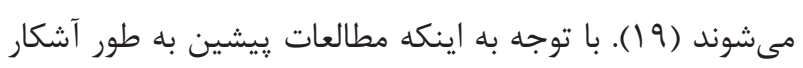

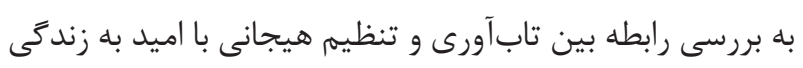

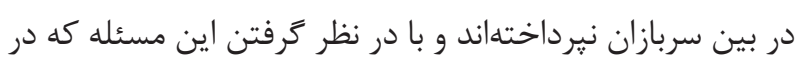

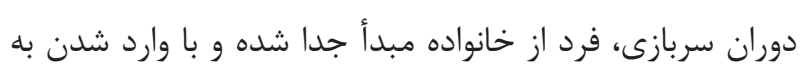

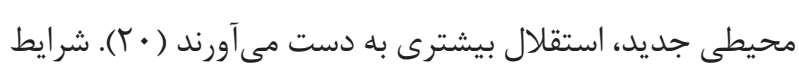

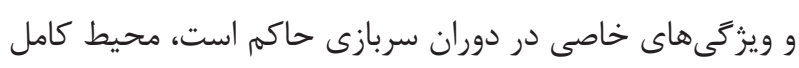

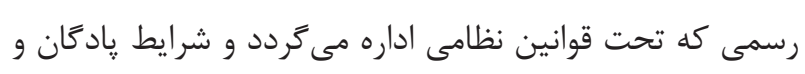

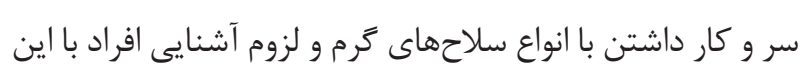

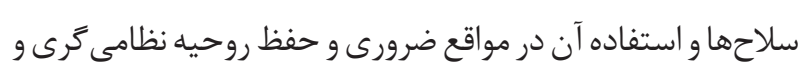

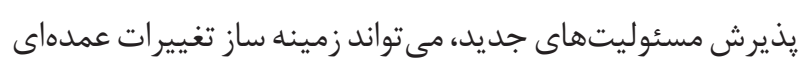

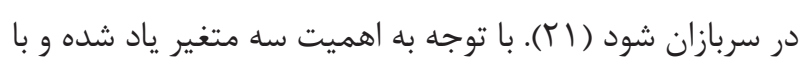

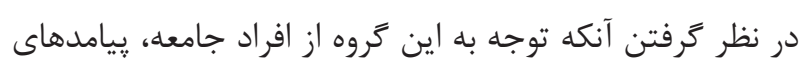

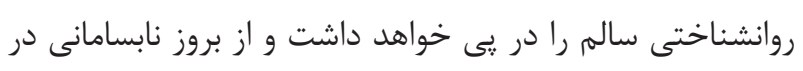

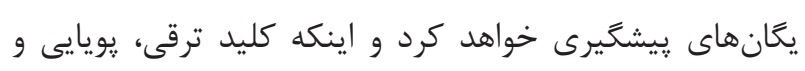
اعتلاى هر جامعهاى در داشتن عناصر و اعضايى سالم و كار آمد

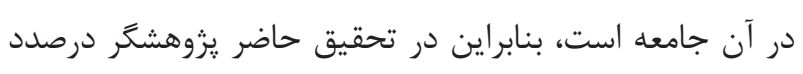

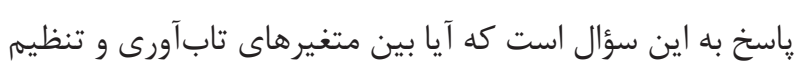

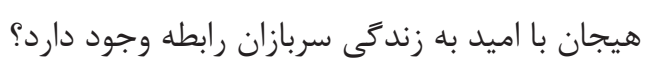

\section{مواد و روشها}

روش يزوهش، توصيفى از نوع همبستكى است زيرا يزوهشكر با

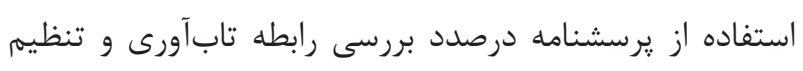

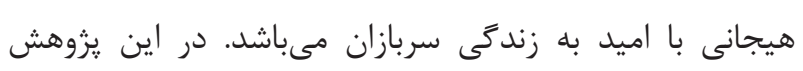

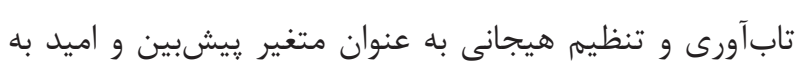
زندَى سربازان به عنوان متغير ملاك در نظر كرفته شدهاند.

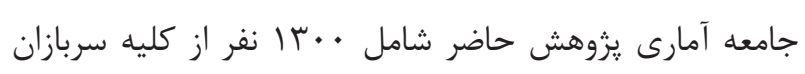

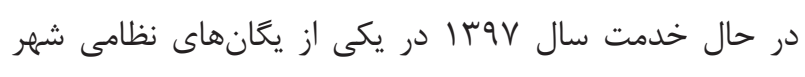

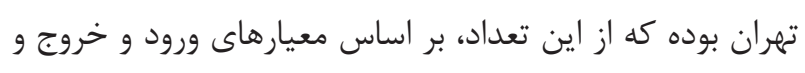

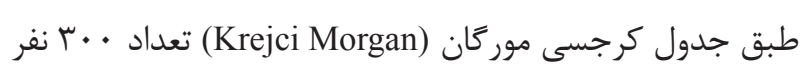

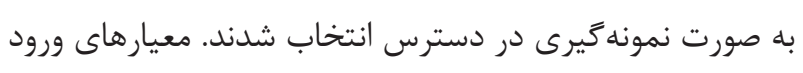

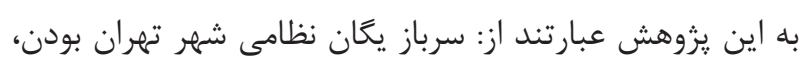

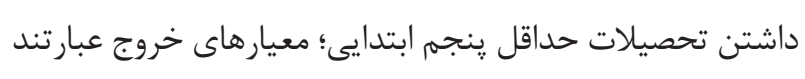
از: فقدان بيمارى روانى و جسمى شديد، نداشتن سابقه اختلالات
خوشبينى و اميد به زندكى زنان سريرست خانوار نشان داد كه

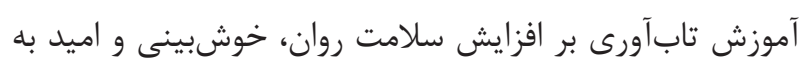
زندگى زنان سريرست خانوار مؤثر بوده است؛ بنابراين، مى توان

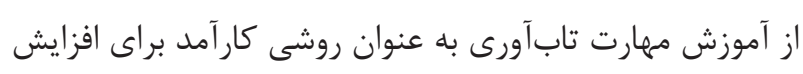

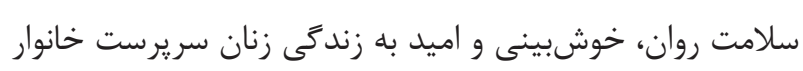

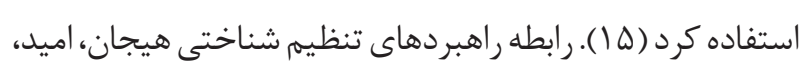
مؤلفههاى اميد و افسردگى در دانشجويان پِر افسرده (غير بيمار )

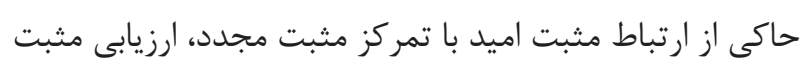

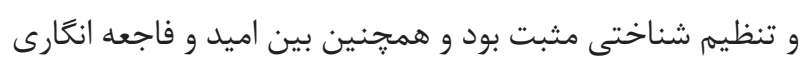

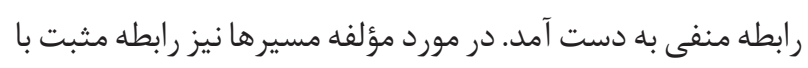

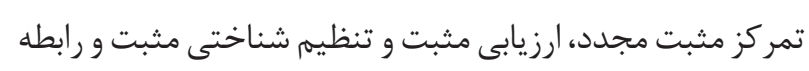

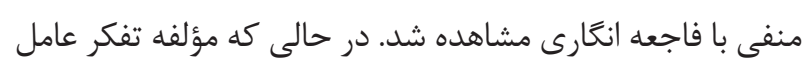

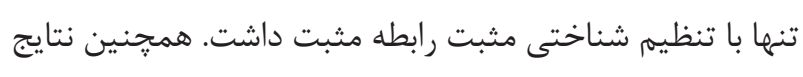

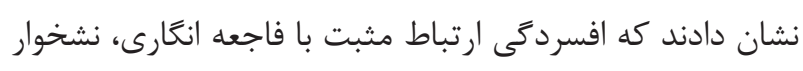
فكرى و يذيرش داشته و داراى ارتباط منفى با ارزيابى مثبت است.

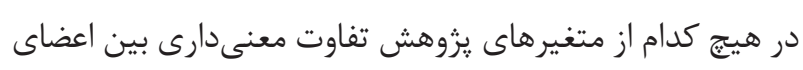

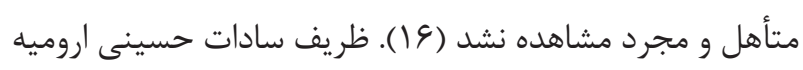

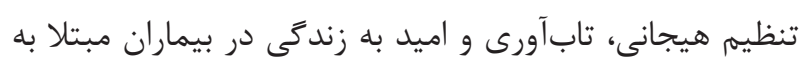

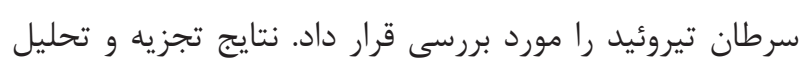

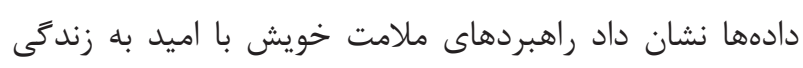

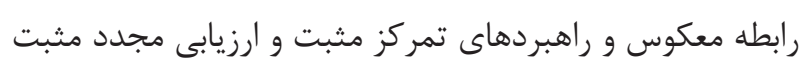
با تاب آورى و اميد به زندكى رابطه مستقيم دارد (V) (IV). همجنين مجدين اميرى در يزوهش خود به اين نتيجه رسيد كه آموزش مهارت

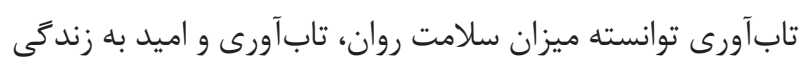
زنان و دختران را افزايش دهد (1) (1).

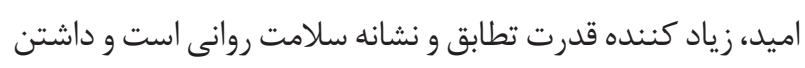
برنامه براى زندگى واقعى همراه با هدف و مقصود واقعى نتيجه

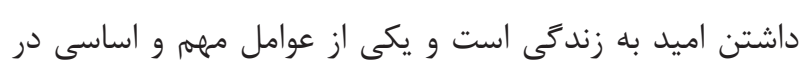
زندگى انسانها اميد و تلاش براى كشف متغيرهاى مؤثر نهفته

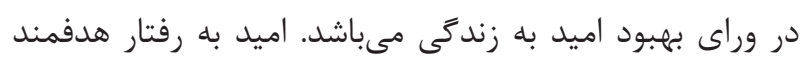

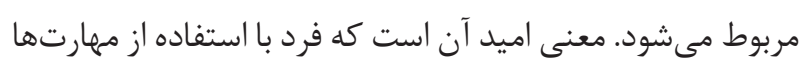

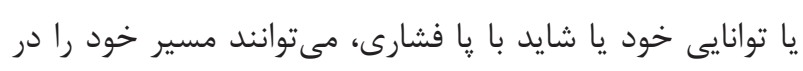

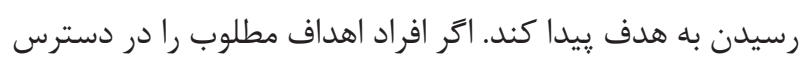

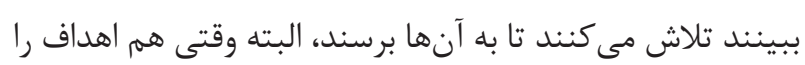


تكانه، توانايى شناختى و مطلوبيت اجتماعى بررسى كردند. به علاوه

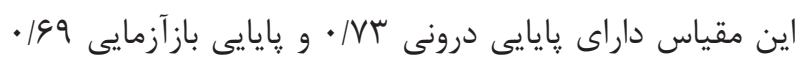

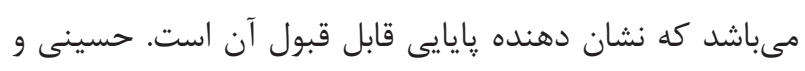

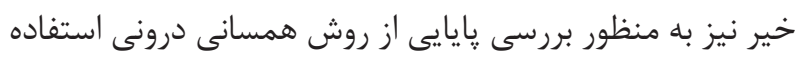

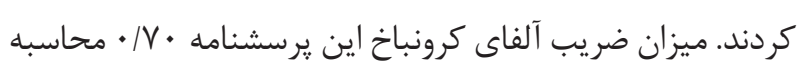

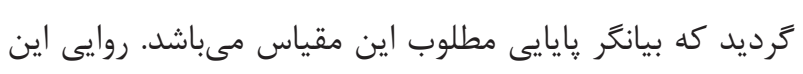

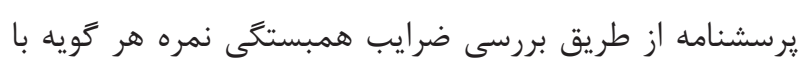

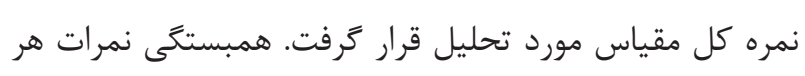

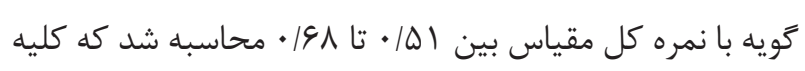

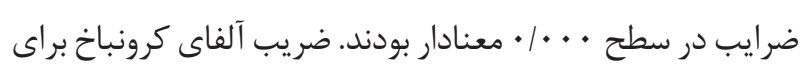

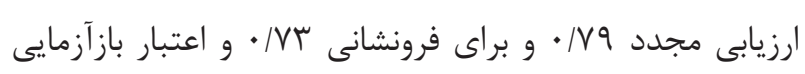

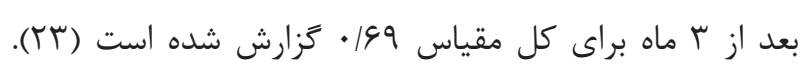

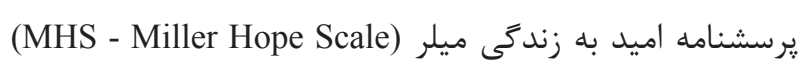

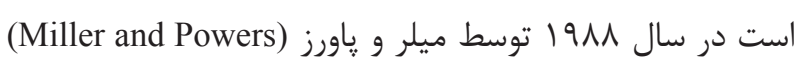

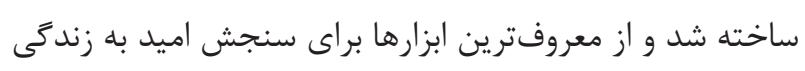

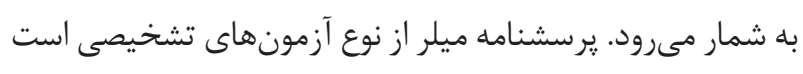
كه اولين بار جهت سنجش اميدوارى بيماران قلبى در آمريكا

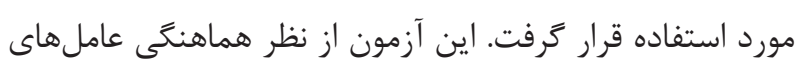

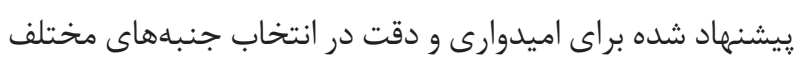

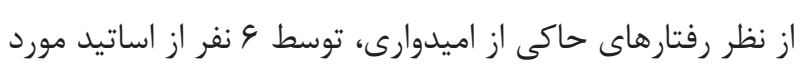

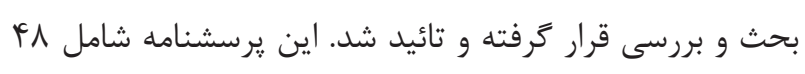
جنبه از حالتهاى اميدوارى و درماندگى است كه مادههاى قيد وريد

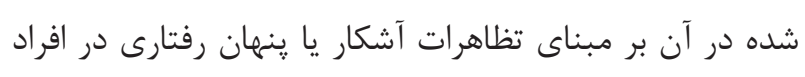

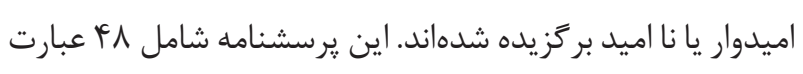

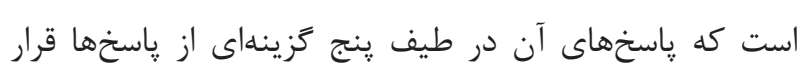

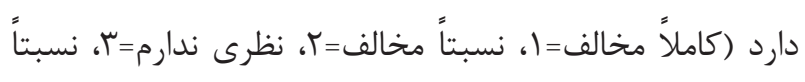

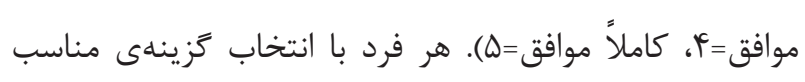
كه براى او صدق مى كند، امتياز كسب مى كند، در آزمون ميلر

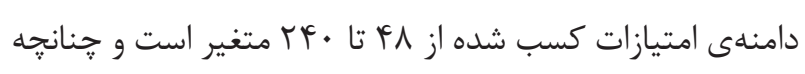

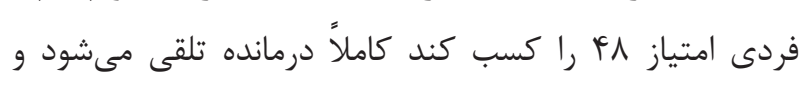

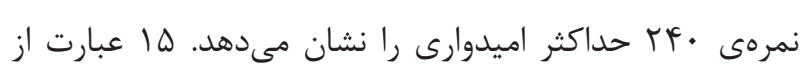
يرسشنامه به طور معكوس نمرهذارى مىشود كه اين شمارهها

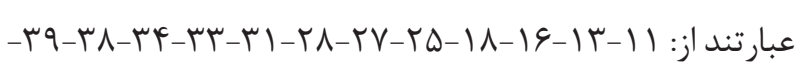

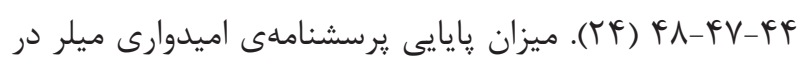

هيجانى. ابزار كردآورى دادهها، يرسشنامههاى، تابآورى كانر و ديويدسون (Conner \& Davidson)، تنظيم هيجانى كراس و جان كردان و واميد به زندگى ميلر (Mohn \& Gross)

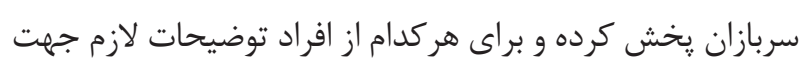
تكميل ياسخنامهها داده شد.

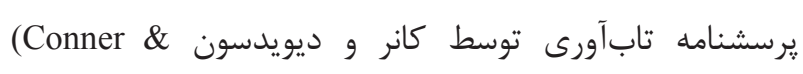

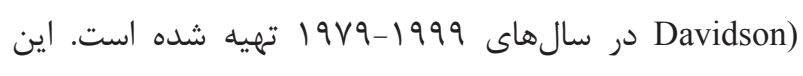
يرسشنامه ها سؤال دارد كه در مقياس ليكرت بين صفر (كاملاً

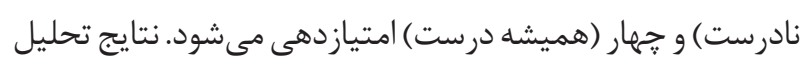

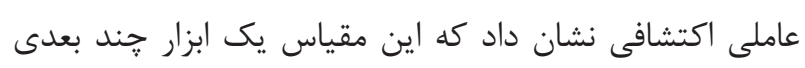

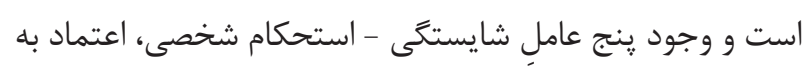

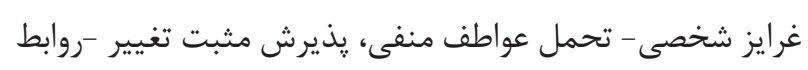

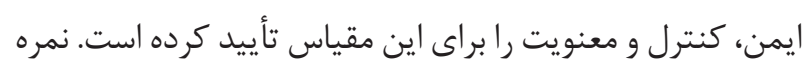

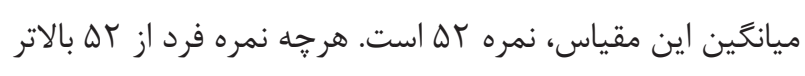

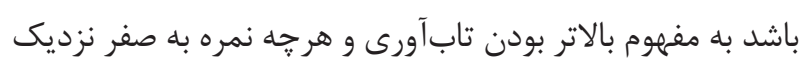

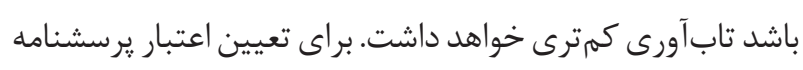

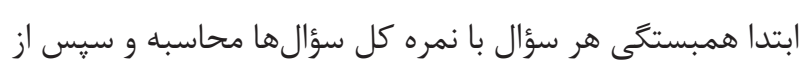

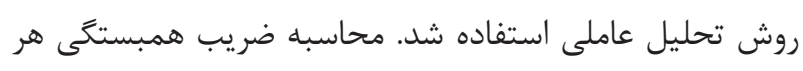

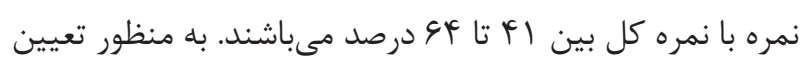

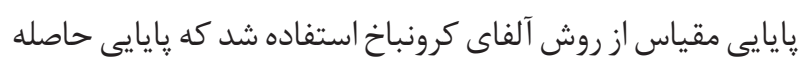

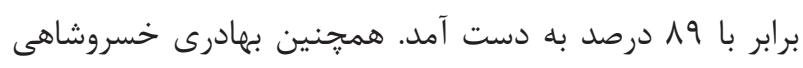

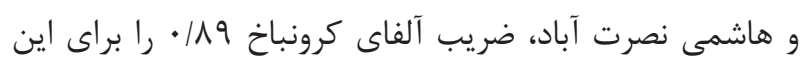

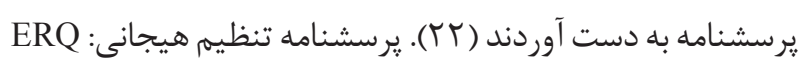
(Emotion Regulation Questionnaire) به منظور اندازهيرى راهبردهاى تنظيم هيجانى (John \& Gross)

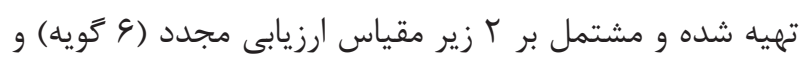

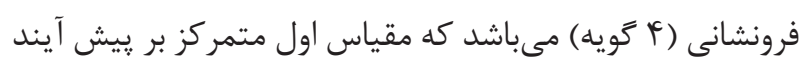

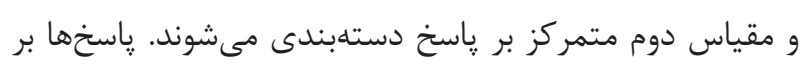

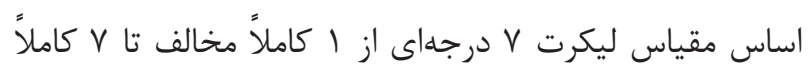

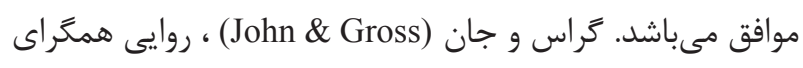

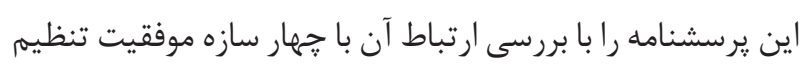

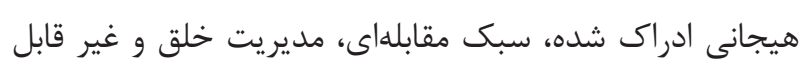

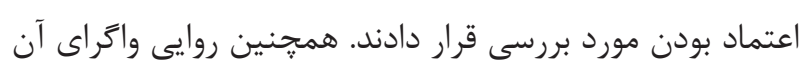

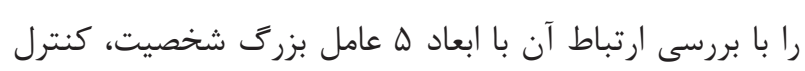


معنادارى ه • • • رابطه مثبت و معنى دارى وجود دارد.

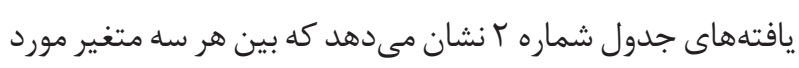

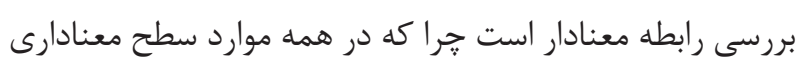

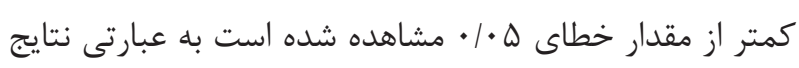

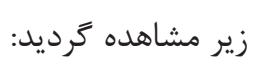

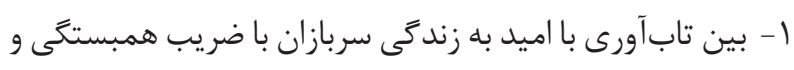

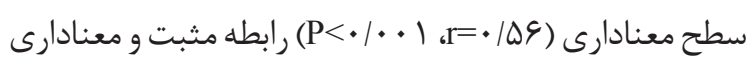

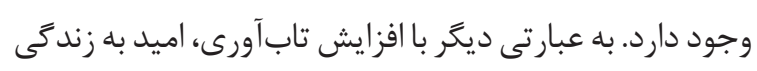

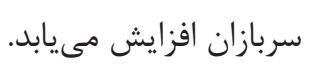

r- بين تنظيم هيجانى (ارزيابى مجدد و فرونشانى) با اميد به زندگى سربازان با ضريب همبستخى و سطح معنادارى (رئي

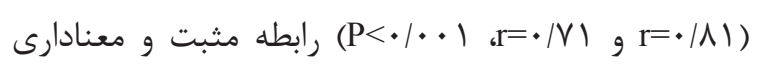
وجود دارد. به عبارتى ديكر بهبود راهبردهاى تنظيم هيجانى

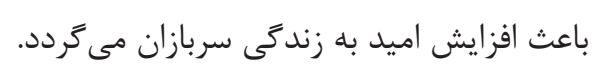

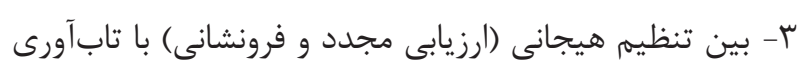

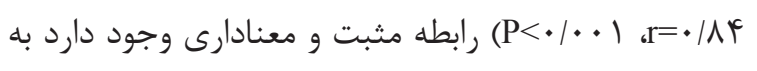

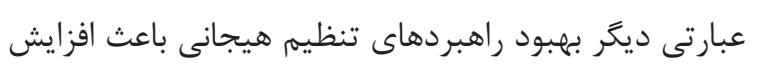

$$
\text { تاب آورى سربازان مى گردد. }
$$

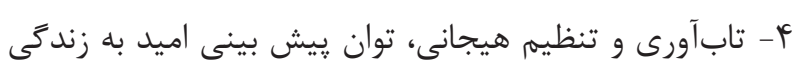

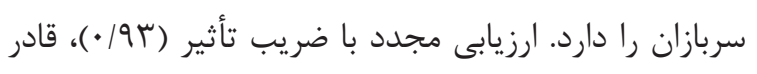
مىباشد تا سهمى از اميد به زندكى سربازان را تبيين نمايد

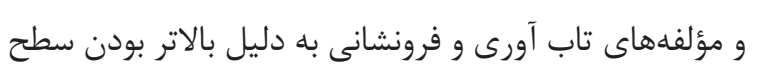

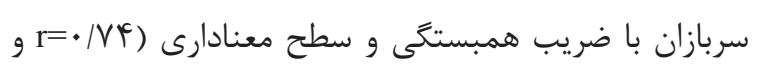

يزوهش در ايران نيز اعتبار و پايايى اين مقياس توسط عبدى و

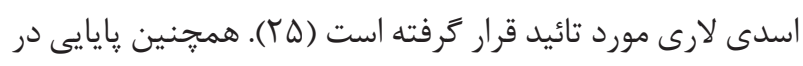

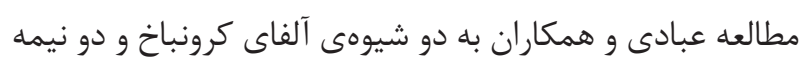

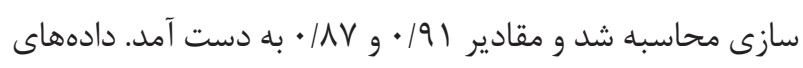

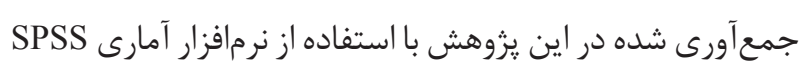

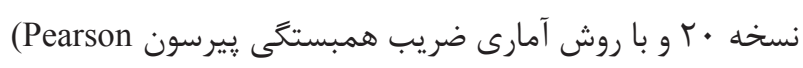

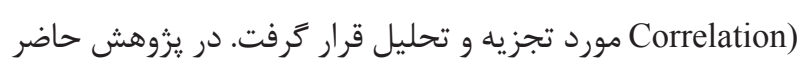
ملاحظات اخلاقى شامل كسب مجوز از كميته اخلاق دانشكاه،

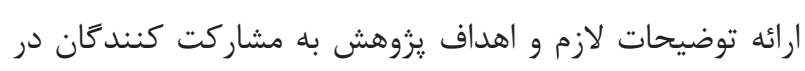

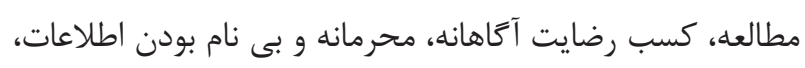
اعلام مجوز خروج از طرح شركت كنندكان در طرح در هر زمان

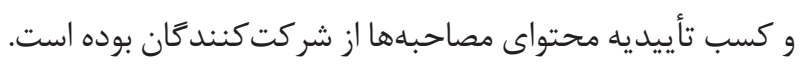

يافتهها

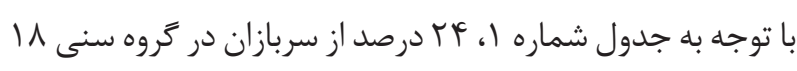

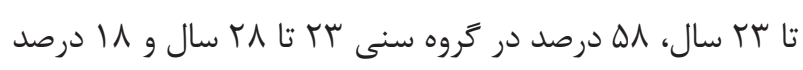

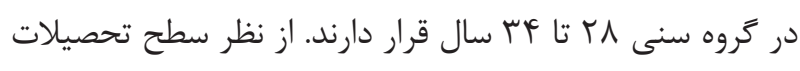

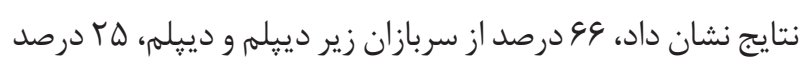
ليسانس و 9 درصد فوق ليسانس مى باشد.

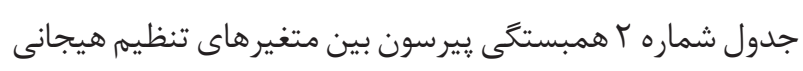

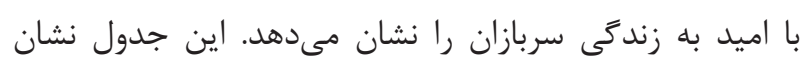

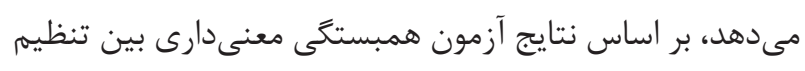

\begin{tabular}{|c|c|c|c|c|c|}
\hline درصد & فراوانى & سطح تحصيلات & درصد & فراوانى & سن (سال) \\
\hline 99 & 191 & دييلم و زير دييلم & $T Y$ & VT & 11 ا تا سז سال \\
\hline$r \Delta$ & $V \Delta$ & ليسانس & $\Delta \Lambda$ & IVF & r ז تا \ץ سال \\
\hline 9 & $T V$ & فوق ليسانس & 11 & $\Delta F$ & ג r تا F سال \\
\hline
\end{tabular}

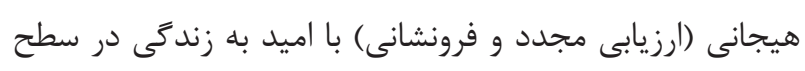

جدول ا- مشخصات فردى سربازان

\begin{tabular}{|c|c|c|c|}
\hline \multicolumn{2}{|c|}{ קِيرسون } & \multirow{2}{*}{ متغير وابسته } & \multirow{2}{*}{ متغير مستقل } \\
\hline سطح معنادارى & ضريب همبستخى & & \\
\hline $\mathrm{P}<\cdot 1 \cdot \cdots 1$ & $\cdot|\Lambda|$ & اميد به زندگى & ارزيابى مجدد \\
\hline $\mathrm{P}<\cdot 1 \cdot \cdots 1$ & $\cdot|V|$ & اميد به زندگى & فرونشانى \\
\hline $\mathrm{P}<\bullet / \bullet \cdot 1$ & $\cdot 109$ & اميد به زندگى & تابآورى \\
\hline
\end{tabular}

جدول r- سنجش همبستكى ميان متغير مستقل و متغير وابسته 
بلهوركلى، افراد تاب آور از توان برنامهريزى براى دستيابى به اهداف برخوردارند، نسبت به خود ديد

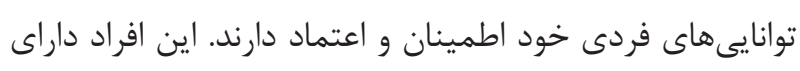

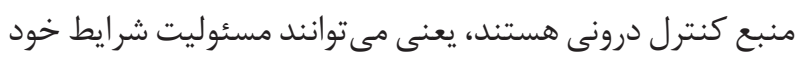

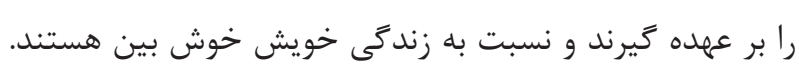

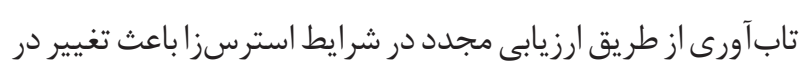

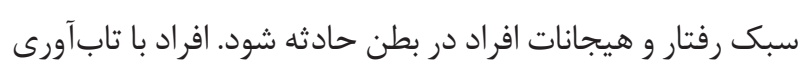
بالا قادرند به شيوه مناسبترى با استرس كنار بيايند و بار ديخر تجارب متناقض خود را تنظيم كنند.

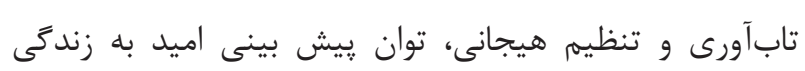

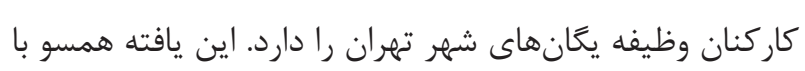

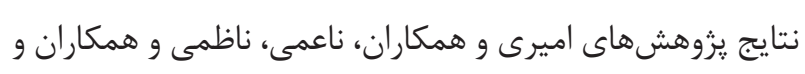

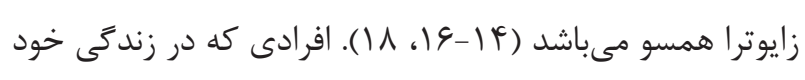
تاب آورى بالايى دارند، رويكرد مثبتى به زندگى داشى داشته و داراى

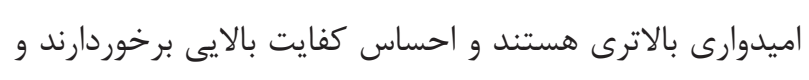
اين افراد معمولاً از سلامت جسمى و روحى خوبى برخوردارند،

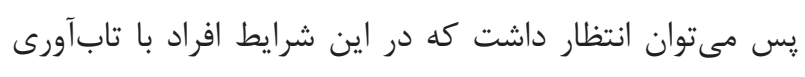
بالا و تنظيم هيجانى مناسب، اميد به زندكى بالاترى ران را تجربه دابه

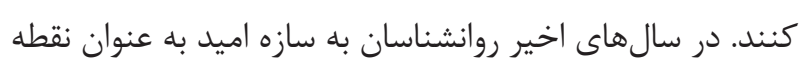
قوت روان شناختى نكريسته كه هم به بالا رفتن تابآورى افراد كمك مى كند و هم در يرورش و ايجاد سلامت روانى مؤثر است.

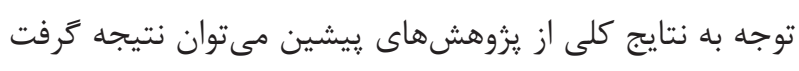
كه وقتى تابآورى و تنظيم هيجانى به صورت مثبت و سازنده

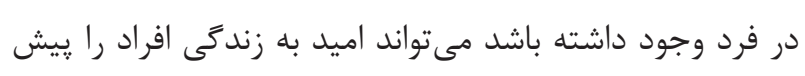

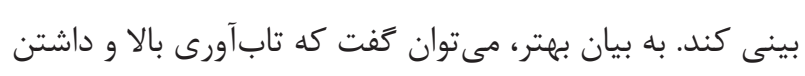

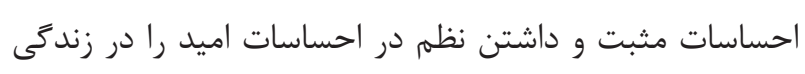
فرد بهبود مى دهند. با توجه به يافتههاى يزوهش بيشنهماد مى شىود، در طراحى و تدوين

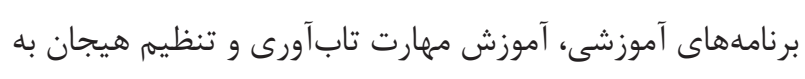

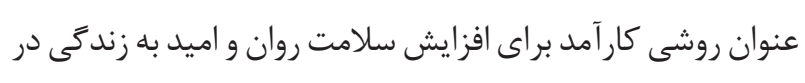

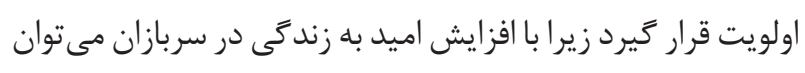
كامى مؤثر در جهت شادابى يكان ها و سازمان ها برداشت، همجنين با آموزش مهارتهايى همانند مهارتهاى ارتباطى، مقابله، جر أت دات

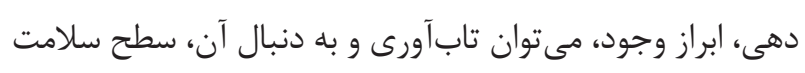

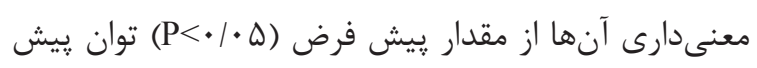

$$
\text { بينى كنندگى اميد به زندى سرى سربازان را ندارند. }
$$

\section{بحث و نتيجه كيرى}

هدف اصلى اين تحقيق بررسى رابطه بين تابآورى و تنظيم نديم

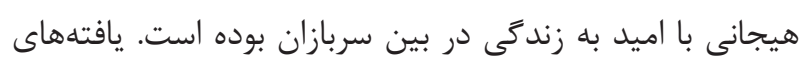

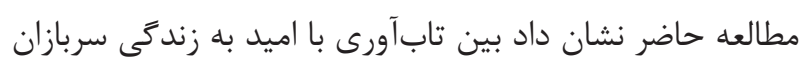

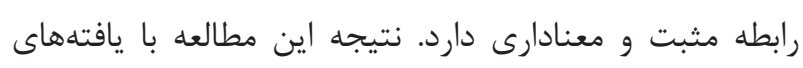
ساير مطالعات ديخر مانند، ناعمى، اميرى و همكاران و زايوترا

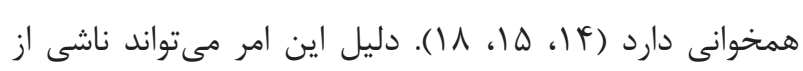

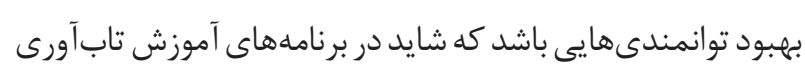

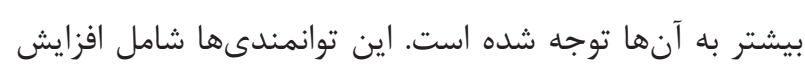

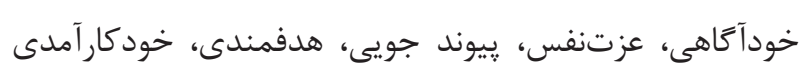

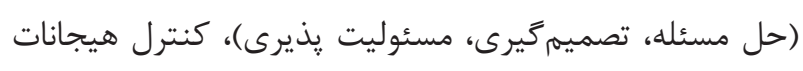

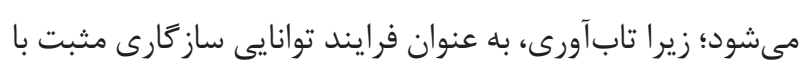

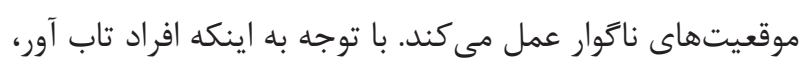

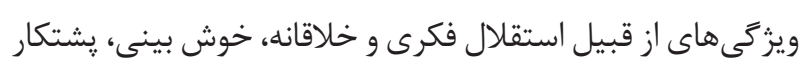

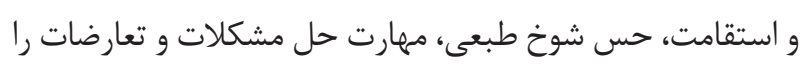

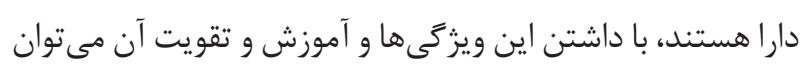

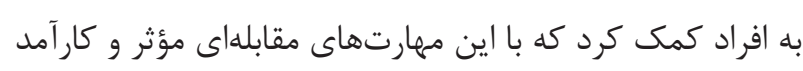
بتوانند به وضعيت مطلوب و به يِيشرفت نائل كردند.

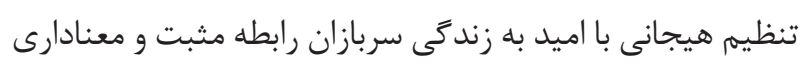

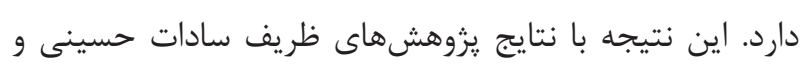

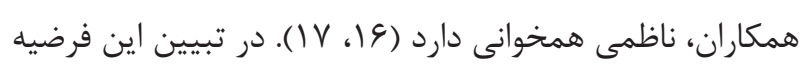

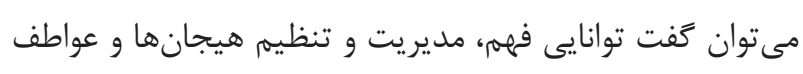

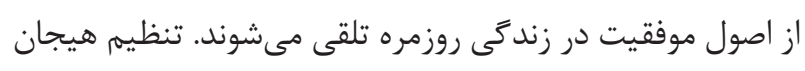

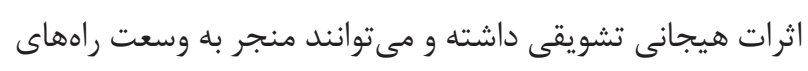
تفكر شوند، باعث ارزيابى بهتر شخص از تجارب روزمره شده و و به ونه

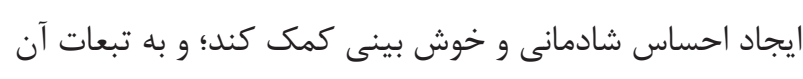

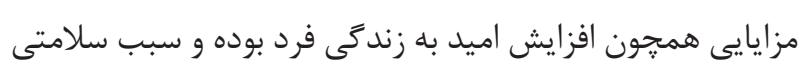
طولانى مدت مى شوند. تابآورى با تنظيم هيجانى سربازان رابطه مثبت و معندوند معنادارى

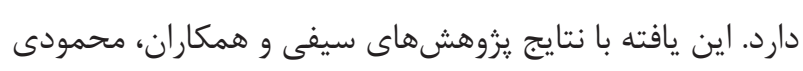

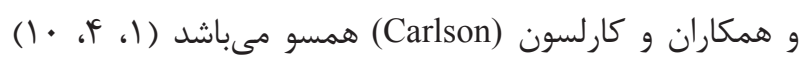


بيانگر آن است كه بين تابآورى و تنظيم هيجانى با اميد به زندگى در بين سربازان رابطه معنى دار وجود دارد؛ بنابر اين توصيه مى گردد براى افزايش اميد به زندگى در سربازان، آموزشهاى متمركز بر

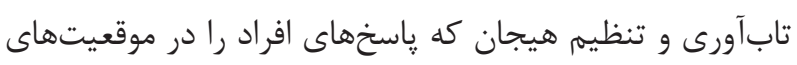
مختلف زندگى بخصوص مواقع بحرانى تحت تأثير قرار داده و باعث

$$
\text { انعطاف ڤذيرى افراد مىشود، ضرورى است. }
$$

$$
\text { تشكر و قدردانى }
$$

بدين وسيله از همكارى تمامى اساتيد، مديران و سربازان عزيزى كه در انجام اين :ززوهش ما را يارى دادند، تشكر و قدردانى مى شعود.

\section{تضاد منافع}

بدين وسيله نويسندگًان تصريح مىنمايند كه هيج گونه تضاد منافعى در خصوص مقاله حاضر وجود ندارد.

\section{References}

1- Mahmoodi K, Ghasemi F. The Relationship between the Cognitive Emotion Regulation and the Resilience among the Iranian Red Crescent Managers. Educational Systems Research. 2017;11(37):93-110.

2- Walklate S, McGarry R, Mythen G. Searching for Resilience. Armed Forces \& Society. 2013;40(3):408-27. http://dx.doi. org/10.1177/0095327x12465419

3- Troy AS, Mauss IB, Southwick SM, Litz B, Charney D, Friedman MJ. Resilience in the face of stress: emotion regulation as a protective factor. Resilience and Mental Health2011. p. 30-44.

4- Carlson JM, Dikecligil GN, Greenberg T, Mujica-Parodi LR. Trait reappraisal is associated with resilience to acute psychological stress. J Research in Personality. 2012;46(5):609-13. http://dx.doi. org/10.1016/j.jrp.2012.05.003

5- Reisi H, Faramarzi S. The Effectiveness of Self-compassion on Self-esteem, Emotion Regulation and Anxiety thoughts in the Children's (10-12 Years) with Depression Disorder in the City of Shahrekord. J Pediatric Nurs. 2019;5(3):17-25.

6- Szczygieł D, Buczny J, Bazińska R. Emotion regulation and emotional information processing: The moderating effect of emotional awareness. Personality and Individual Differences. 2012;52(3):433-7. http://dx.doi.org/10.1016/j.paid.2011.11.005

7- Theurel A, Gentaz E. The regulation of emotions in adolescents: Age differences and emotion-specific patterns. PLoS One. 2018;13(6):e0195501. http://dx.doi.org/10.1371/journal.
سربازان را افزايش داد و در برنامهريزى كلان آموزشى و تربيتى مرتبط با سربازان و خدمات رسانى به اين گروه بزرت و مؤثر در جامعه، با ديدى وسيع ابعاد گسترده عوامل روانشناختى تأثير گذار در روند ايجاد و تداوم سلامت و اميد به زندگى لحاظ گردد. از جمله محدوديتهاى مهرم در اين يزوهش جامعه آمارى يزوهش حاضر است، نمونه آمارى به صورت در دسترس انتخاب شده است، لذا، در تعميم نتايج به ساير سربازان احتياط و دقت لازم به عمل آيد. بدون ترديد يزوهشهاى آتى در جمعيتهاى متفاوت و نيز در نمونههاى بالينى مىتواند گسترههاى تازهاى در مورد رابطه

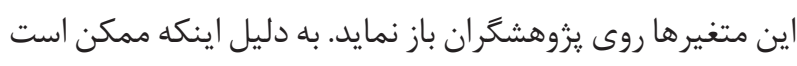
در ير كردن برسشنامهها نظرات بر اساس سلايق شخصى باشد و بر اساس واقعيتها نباشد و به دليل همكارى ضعيف برخى از آزمودنىها امكان سوَيرى در ياسخها وجود دارد، يزوهشگران مطالعه حاضر براى كنترل اين محدوديت سعى نمودند با برقرارى ارتباط مناسب، اعتماد واحدهاى يزوهش را جلب كنند. يافتهها

8- Ismaili L, Aghaei A, Abedi M, Ismaili M. The Effect of Teaching Exercise Setting on the Mental Health of Acolyte Girls. Journal of Mazandaran University of Medical Sciences 2011;5(20):31-43.

9- Hashemzadeh S. The Relationship Between Resilience and Emotion Settlement in Payame Noor University Students in Gonbad-Kavoos City. International Conference on Modern Approaches to Humanities, Management, Economics and Accounting2017.

10- Saifi V, Farzin Rad B. Relation of Excitement, Anxiety and Depression with Resilience in Students. The first international conference on modern research in the field of education and psychology and social studies of Iran2017.

11- Mirmahdi S, RezaAli M. The Effectiveness of Mindfulnessbased Cognitive Therapy on Resilince, Emotion Regulation and Life Expectancy among Women with Diabetes2. J Research in Psychology of Health 2017;4(28):167-83.

12- Afshani S, Ja'fari Z. Religious Relations and Hope for the Future among Students at Yazd University. Farhang University of Islamic Sciences 2017;19(6):191-210.

13- RajabiPourMeybodi A, DostHosseini F. The effect of spiritual health on academic burnout with the role of Minji Life expectancy. J Biology Ethics. 2018;8(28):40-7.

14- Zautra AJ, Hall JS, Murray KE. A new definition of health for people and communities. New York, London: The Guilford Press; 2010.

15- Naimi AM. The Effectiveness of Family-Based Education on 
Mental Health and Resilience of Widowed Wives. Women in Development and Politics 2015;1(13):41-52.

16- Nazmi Harandi J, Namdari C. The Relationship between Emotion Cognitive Regulation, Hope, Hope Components and Depression in Depressed (Non-Patient) Students in Isfahan University. Third National Conference on Psychology and Behavioral Sciences; Tehran2015.

17- Hosseini Z, Urmia L, Isfahani Khaleghi A, Bunkardari N. Emotion regulation, resiliency and life expectancy in patients with thyroid cancer. In: Tehran, editor. the 6th Congress of the Iranian Psychological Association2017.

18- Amiri B, Mohammadi C, Goodarzian M, Mousavi SF. Improvement of Resilience Skills on Life Expectancy Mental Health and Resilience of Women and Girls in Khuzestan Province. Fourth Conference on Positive Psychology; Bandar Abbas2017.

19- QharaeZibaii F, AliAkbariDehkordi M, Alipour, Mohtashami T. Efficacy of Group logo Therapy in the perceived Stress and life Expectancy in MS patients. Research in psychological health 2010;6(4):20-12.

20- Daneshfard K, Zakeri M. Effect of military training courses on psychological empowerment of soldiers under training. Quarterly Military Management 2012;45(12):43-62.

21- Nosratabadi M, Halvaiepour Z. Explaining Suicide Ideation Based on Drug Abuse and Depression in Soldiers of Aja University of Medical Science. J Mil Med. 2016;17(4):249-55.

22- Robertson DR, Holzenthal RW. Revision of the Neotropical caddisfly genus Itauara Muller, 1888 (Trichoptera, Glossosomatidae). Zookeys. 2011(114):41-100. http://dx.doi. org/10.3897/zookeys.114.1405 www.ncbi.nlm.nih.gov/ pubmed/21976996

23- Besharat M. Cognitive Emotion Regulation Questionnaire: Instruction and Scoring Developmental Pschology: Iranian Psychologists 2017;13(50):221-3.

24- Miller JF, Powers MJ. Development of an instrument to measure hope. Nurs Res. 1988;37(1):6-10. www.ncbi.nlm.nih.gov/ pubmed $/ 3340583$

25- Abdi N, Asady Lari M. Standardization of three Hope scale, as possible measures at the end of life. Iranian Journal of Cancer Prevention 2011;2:71-7. 